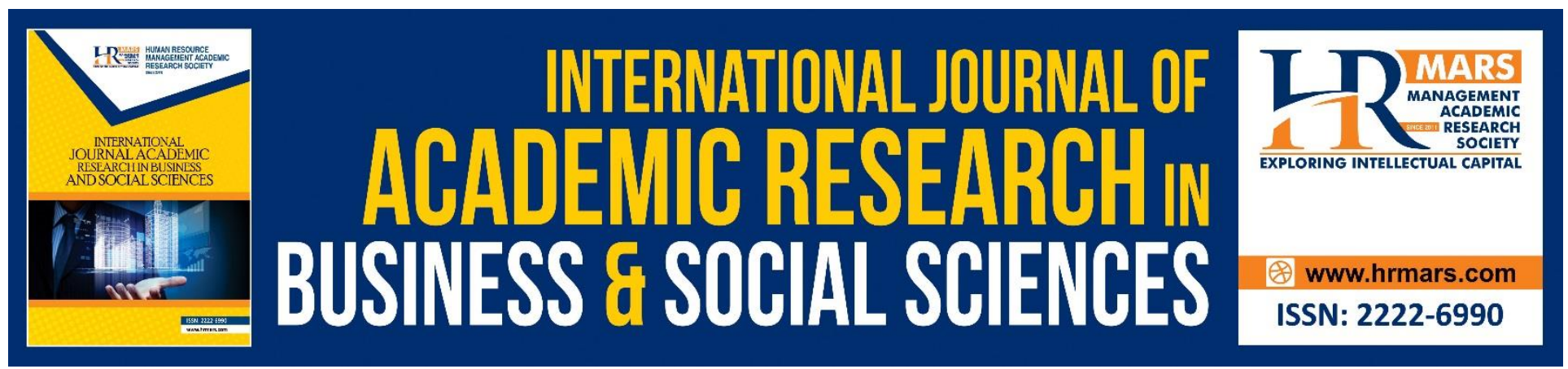

\title{
Communicating Corporate Image Online: A Case of National Defense University of Malaysia's Website
}

\author{
Aida Nasirah Abdullah, Zailin Zainal Ariffin, Khairunnisa Mardzuki, Norlaila \\ Mazura Mohaiyadin, Amanah Saayah Ismail
}

To Link this Article: http://dx.doi.org/10.6007/IJARBSS/v9-i6/6058

DOI: $10.6007 /$ IJARBSS/v9-i6/6058

Received: 19 April 2019, Revised: 20 May 2019, Accepted: 01 June 2019

Published Online: 24 June 2019

In-Text Citation: (Abdullah, Ariffin, Mardzuki, Mohaiyadin, \& Ismail, 2019)

To Cite this Article: Abdullah, A. N., Ariffin, Z. Z., Mardzuki, K., Mohaiyadin, N. M., \& Ismail, A. S. (2019). Communicating Corporate Image Online: A Case of National Defense University of Malaysia's Website. International Journal of Academic Research in Business and Social Sciences, 9(6), 967-975.

Copyright: (C) 2019 The Author(s)

Published by Human Resource Management Academic Research Society (www.hrmars.com)

This article is published under the Creative Commons Attribution (CC BY 4.0) license. Anyone may reproduce, distribute, translate and create derivative works of this article (for both commercial and non-commercial purposes), subject to full attribution to the original publication and authors. The full terms of this license may be seen

at: http://creativecommons.org/licences/by/4.0/legalcode

$$
\text { Vol. 9, No. 6, 2019, Pg. } 967-975
$$

Full Terms \& Conditions of access and use can be found at http://hrmars.com/index.php/pages/detail/publication-ethics 


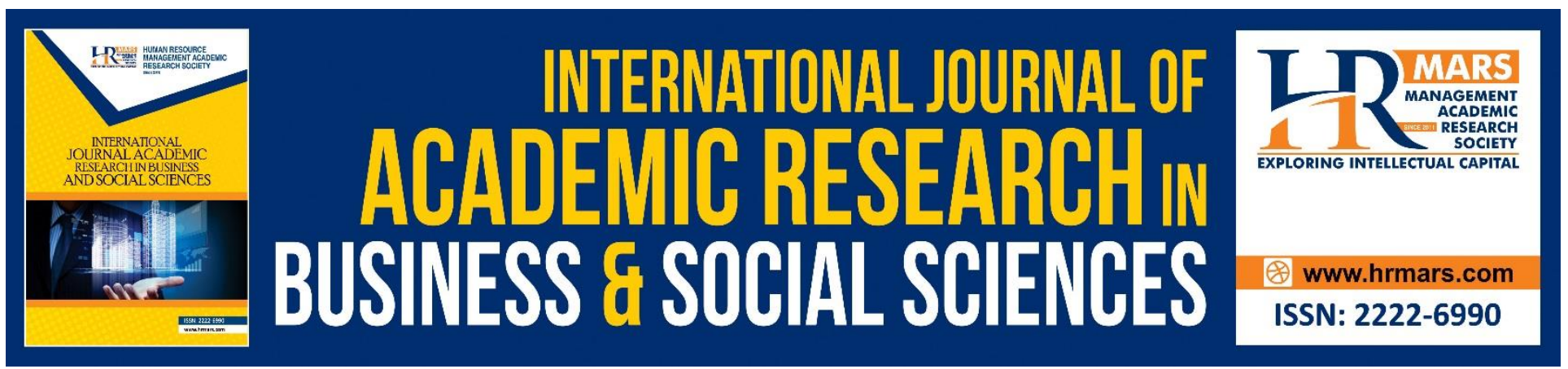

\title{
Communicating Corporate Image Online: A Case of National Defense University of Malaysia's Website
}

\author{
Aida Nasirah Abdullah, Zailin Zainal Ariffin, Khairunnisa Mardzuki, \\ Norlaila Mazura Mohaiyadin, Amanah Saayah Ismail \\ Department of Defense Human Resource Management, Faculty of Defense Studies and \\ Management, National Defense University of Malaysia, \\ Email: aidanasirah@upnm.edu.my,zailin@upnm.edu.my,nisamardzuki@upnm.edu.my, \\ norlaila@upnm.edu.my,amnah@upnm.edu.my
}

\begin{abstract}
The extent to which website of the National Defense University of Malaysia (NDUM) complies with the best practice design guideline to communicate its corporate image was analyzed. Content analysis was employed to measure twenty-four web design features available on NDUM website. The findings showed that the site was categorized as moderately well- designed. Therefore, improving the NDUM's website is suggested so that it can act as a gateway to the university's image as a premier Defense University in the region. This study will be an addition to web design literature and facilitate universities and individuals to develop effective strategies to elevate the image of universities in the global context.
\end{abstract}

Keywords: Website, Web Design, Homepage, Corporate Image

\section{Introduction}

In corporate world, the web seems to be a primary interface between the organization and its clients and stakeholders. The organization website plays an important role in fulfilling its customers' expectation. In the scenario where the competitions in the global higher education have increased, the issue of how to profile the good image of the higher institutions has also increased. University websites serve as a main marketing platform to provide useful information and communication opportunities which reflect the corporate image of the universities.

Effective website is essential to all academic organizations that endeavor to communicate its corporate image and its products to their audiences. Only by raising awareness of services offered to the general public through the right channel - which then facilitates education - can an academic organization successfully achieve its vision and mission online. In fact, this activity is the very reason why university website exists. Apart from communicating with various stakeholders such as students, 
faculty, staff and visitors efficiently and timely, the university's website can also shape its corporate image online. Universities need to do everything within their power to keep positive image with their various constituents, and one way to do this is to make use of the opportunities website presents.

The National Defense University of Malaysia (NDUM), like other universities is also focusing on its website to ascertain its web design elements so that its website could portray its corporate image and its success. The university is responsible in upgrading the knowledge and academic status of the armed forces by offering bachelor degree courses in fields of engineering, sciences and managements. The NDUM seeks to accomplish its mission - "To be the premier Defense university in the region for education, training and knowledge creation". Standing strong with its motto "DUTY, HONOUR, INTEGRITY", NDUM is committed to excel as a premier Defense university in the region. This clearly reflects that the NDUM has its own corporate image to boast in order to create a bond of trust between the marketplace.

\section{Literature Review}

According to Dictionary.com, corporate image refers to a company's reputation and can be described as a mental representation, idea or a concept. It is the immediate mental picture that audiences have of an organization (Gray \& Balmer, 1998). NOIE (2003) basically divided corporate image into three categories, that is interior and exterior image, physical and virtual image, and internal and external image. Literally, a company image is an accepted view of what a company stands for, revealing it at a corporate level, as the "image" is what the public expects to see when the corporation is mentioned (Gray \& Balmer, 1998).

Gray and Balmer (1998) stressed that the survival of an organization could be attributed to its ability to attain and retain a good image in today's sensitive business world. In order for an organization to pull the interest among the customers, it definitely needs to design its image to be appealing in order to build close relationships with its clients, spark an interest among consumers, create share of mind and profile brand quality (Dowling, 1994).

As online era emerges, institutions have to compete globally as their brand has become a business asset just like their human, capital and financial resources (Moore 2004). Today, the Information and Communication technologies through the web consequently seem to be the essential tools for the organizations to market the products and services. As a result, many organizations including the universities adopt communication strategies through the web to impart information, market products or services and build relationship.

For a long time before the emergence of the Internet, the universities utilized marketing or advertising strategies to create and emphasize their image via tradition channel e.g., in the form of posters, flyers, and other printed promotional materials. However, in 2004, more people used the internet to search information about a college or university (Hitlin \& Rainie, 2005). Bao \& Ellis (2007) conducted a content analysis on 31 universities around the world on standard web features and usability, using Nielsen \& Tahir's (2002) heuristic guideline and Nichani's (2006) information architecture aspects. They revealed that British and Australian universities were more compliant with web standards, web design and usability issues.

Today it is common that university websites serve as a main marketing platform for providing useful information and communication opportunities which reflect the university's image or the 
brand. The brand is considered extremely important as brand gives impact with regards to students' enrolment and staff's recruitment, resources attraction and goodwill creation (Zanariah et. al., 2015). Kang \& Norton (2006) conducted a content analysis of 129 university web sites design in the US whereby they noted that web design is essential for universities to reflect their corporate images and attract the stakeholders.

A website can provide a university with a highly effective device for communication if the site is both usable and useful to visitors. Creating a well-designed and a quality website involves a proper strategy and planning. Visual appearance is one of the essential aspects of web design. Therefore it is crucial for any university to develop an effective website that can support an outstanding organization corporate image and reputation.

To endeavor sustainable development, effective website is very important to all universities as they can promote their corporate image, market their educational products, raise issues and awareness in both general public and interested parties. By having an effective website, they can facilitate education awareness among the public. All these activities constitute the answers to how the universities can successfully communicate and support their missions and goals via online. It is due to these activities that materialise the existence of the universities online (Zanariah et. al., 2015).

Nielsen (2000) and Nielsen and Norman (2000) mentioned that web design normally includes the combination of layout, interactivity and navigation. Nielsen (2000), who is referred to as the guru of web-design, emphasized that interactivity, design, and navigation were important features in a website. The design should always reflect the needs of users. Aydin et al., (2010) and Nasirah (2014) reported that a well-designed website could communicate the organization's corporate image to the public as information about the organization can be accessed instantaneously from all over the world. Nasirah (2013) also reported that a good website has to be supported by a good team of professionals (webmasters, researchers, IT experts, and others). The website professionals are needed to oversee the design, collection and display of sufficient and useful information, fund allocation, and other pertinent resources to ensure that the websites function effectively.

Nielsen (2000) and McLachlan (2002) highlighted that measuring web presentation from the design point of view requires evaluating the visuals, layout, graphics, color combinations, amount of information displayed, the overall organization of information gelled with sitemaps, navigation bars, form design, font styles and sizes, and the aesthetic appeal of the website (Spencer, 2002; Ivory, 2003). Winn and Beck's (2002) stated that the design elements of websites had power to persuade, and that contributed to more successful websites. Brinck (2001) emphasized that design and art creativity were equally important in a website.

Scharl (2006) pointed that a good quality website that communicates effectively must possess best practice elements such as useful, relevant and trustworthy information to encourage awareness. Apart from that, it must be interactive so that it can get input and feedback from both the developers and the users. The navigation of the site must be intuitive too so that the levels of the website can be easily linked and information easily accessed; and the design of the site must be proactive to make it interesting and able to communicate information successfully. 


\section{Research Method}

The aim of this research is to investigate if the UPNM corporate image might be influenced by its website. We conducted web content analysis as Scharl (2006) argued that web content analysis helps to explore what real websites developers consider while producing their websites. The content analysis of NDUM's website experienced tough time because the site went through the enhancement exercises few times so it disturbed the process. This is in agreement with Burnet and Marshall (2003) who claimed that website analysis is not easy as a website's appearance can change over time even though it follows certain patterns.

The content analysis of NDUM website was conducted from April to December 2017 in attempt to address the issue. Both qualitative and quantitative methods were used in this study to increase the validity of the findings by collecting data from multiple perspectives (Denzin, 1989; Marvasti, 2004). For qualitative approach, we coded useful, relevant and trustworthy information that could communicate corporate information and corporate image successfully. The coding process identified three types of information, i.e., background/history of the organization; corporate information such as the group name, banner, logo, and motto; and contact information as significant in any organization website. Units such as mission; vision; philosophy; background; organization name; logo, and motto which portray the NDUM corporate identity were analyzed. In order to investigate how NDUM effectively communicate its corporate image online, this study first explored its mission and goals. Mission, vision and philosophy of an organization are important because the information can generate trust and belief in the activities of an organization.

For quantitative approach, we adopted the "WWW CyberGuide" developed by Karen McLahlan (2002) with eight main web features such as speed, homepage, ease of navigation, use of multimedia, browser compatibility, content presentation, currency and availability of further information. The features were then detailed out into 24 units of analysis. Among the criteria coded are homepage attractiveness; can tell where you are; clear index, table of content; user able to move with ease; directions are easy to follow; links are helpful; graphics serve clear purpose; sufficient information; information clearly organized; etc. A Likert scale was used to evaluate the design feature existing on the NDUM website. In order to classify the site as 'very well-designed', 'well-designed', 'moderately well-designed', 'poorly designed', and 'very poorly designed', the general census was given based on the total number of design features available on the sites: 20 to $24=$ very welldesigned; 15 to 19 = well-designed; 10 to $14=$ moderately well-designed; 5 to $9=$ poorly designed; and 0 to $4=$ very poorly designed.

\section{Result and Discussion}

The web content analysis demonstrated that NDUM has a relatively small website, providing useful information related to NDUM's corporate image. Overall, the NDUM site was moderately welldesigned. NDUM website provided the most important, useful and relevant corporate information, that is the university's mission and vision statements. NDUM's vision - "To be the premier Defense university in the region for education, training and knowledge creation." was essential to directly communicate the NDUM's corporate image to the public as it reflected the authority of the university. It also could encourage the creation of trust, which is considered to be a vital aspect of corporate relationship with the public. The NDUM's mission given is quite long. Apart from that UPNM site also 
provided information about the university's philosophy: "The premier national institution dedicated to producing intellectual leaders of character committed towards selfless service to the nation in furtherance of national strategic interests." Consequently, the information was relevant as it reflected the organizations' scope of its operation and also its fundamental purpose and character in education.

The standard contact information about NDUM was also found on its and it was prominently placed. This allowed the public to communicate with them easily. The contact information included location address, email address, telephone and fax numbers could support its outreach efforts and relationship with the public. The information was current, useful, relevant, and reflected the NDUM's authority as a public university. Adequate and correct contact information is essential as NDUM needs to inform people where it is located and how people can contact or interact with them. Sufficient contact information would allow NDUM to communicate its corporate image successfully and effectively.

Besides that, NDUM's site also provided the organization logo which was placed and portrayed prominently on the left hand side of the website. Running across the webpage together with the logo were the organization name, the organization motto: DUTY, HONOUR, INTEGRITY and three other related logos positioned on the right hand side of the website. Motto or sometimes also known as 'tagline' usually is precise and short in a sentence or phrase encapsulating a belief or ideal. This is in agreement with Sehmel (2004) who stressed that taglines were another way to brand. Therefore, the NDUM's motto portrayed the corporate identity of NDUM.

Design characteristics of the website, for example the visual elements, were considered elements that drew people's attention and often appealed to their values and emotions. Web design contributes to the ease of use of the sites and has strong elements that might draw people's attention to the campaigns and encourage them to have dialogues.

The findings indicated that website design features existed quite substantially on NDUM website. The availability of those features coded indicated that the NDUM website designs supported the organization effectively to communicate its corporate image to the people at large.

The NDUM homepage downloaded efficiently. Via its homepage, user could tell where they were immediately. However, the homepage was not attractive, as it did not possess strong eye appeal feature. The presentation of the homepage and other pages was not eye appeal and it was not spiced up with some contrast of color. The index, table of content and other clear indicator of the content of the site were available NDUM's site. At the same time, the site sponsor was clearly identified and the information/method for contacting the web provider was readily available on the homepage. The copyright date or the date when the site was established was easy to determine.

The NDUM site was user friendly as users could move around within the site with ease. Directions for using the site were provided clearly. The links to other pages within the site were helpful and appropriate whereby both the internal and external links were working properly. There were not many dead ends, incorrect links, etc. The NDUM site did not use multimedia so much as there were no graphics, sound clips etc. Nevertheless, the site was quite effective with a variety of browsers such as Netscape and Internet Explorer provided. 
As for the content presentation, the NDUM site provided sufficient information to make the site worth visiting. Almost all information were clearly presented, labelled and organized. The site was eye soothing as the same basic format was used consistently throughout the site. However, overall, information was quite difficult to be found because more often than not, the user had to three clicks or more. Moreover, the lists of links were not so well organized and were not so easy to use. Even though the information available on the NDUM site were current, but there were still outdated materials not removed. The site also did not provide the working link to a contact person or address for further information. On the other hand however, links to other useful websites were provided. Overall, the quantitative results supported the qualitative results which indicated that the NDUM site was 'moderately well-designed' as 13 of the 24 (54\%) good web design features were present.

\section{Conclusion}

The result of the study would potentially help NDUM to make a significant difference in the effectiveness of the website design process and therefore could effectively communicate its corporate image online. The findings suggested that the NDUM site needs to be improved in term of its design. As a good website has to be supported by a good team of professionals such as webmasters, researchers and IT experts (Nasirah, 2014), therefore, the website professionals are needed to oversee the design, collection and display of sufficient and useful information, fund allocation, and other pertinent resources to ensure that the websites function effectively. Therefore, it is suggested that the NDUM increase IT knowledge, especially on web development and design, training, provide support for free-lance web designers, enhance communication skills online, and get help from education specialist at the same time. Good university websites must come from good communication between academics and IT experts to ideally produce their websites. The people in charge of the websites must also have a passion for their websites.

As this study is solely and only conducted in the view of the researcher as the 'user' of the websites - rather, it is one user's interpretation of the opportunities web users can leverage using the Internet, therefore it is suggested that future research conducts the usability study of NDUM site. It is necessary because conducting usability tests involving all potential site users will help improve the navigability of websites and their overall effectiveness.

Apart from this, it is suggested that the NDUM provides alternatives to text-based information - namely, videos and graphics. The NDUM also should update their sites more frequently as some information on their sites was out of date. This is essential as the NDUM can give the audience the impression that its site and its content are important to both the organization and the audience. Apparently, information on "last updated" page is also essential in order to notify users as to how current the information is.

\section{Acknowledgement}

I am so thankful to my fellow co-researchers whose challenges and productive critics, have provided new ideas to the work. I am also grateful to the National Defense University of Malaysia for providing the short term research grant scheme for making it possible for me to study its official website. 
INTERNATIONAL JOURNAL OF ACADEMIC RESEARCH IN BUSINESS AND SOCIAL SCIENCES

Vol. 9, No. 6, June, 2019, E-ISSN: 2222-6990 (C) 2019 HRMARS

\section{Corresponding Author}

Aida Nasirah Abdullah, Department of Defense Human Resource Management, Faculty of Defense Studies and Management, National Defense University of Malaysia, MALAYSIA,

Email: aidanasirah@upnm.edu.my, Sungai Besi Camp, 57000 Kuala Lumpur, Malaysia.

\section{References}

1. Abdullah, A. N., Husain, K., \& Mohin, M. (2013). Environmental online campaigns through website interactivity: The case of Malaysian Environmental NGOs (MENGO). Journal of Human Capital Development, 6(2), 81-98.

2. Abdullah, A. N., \& Bolong, J. (2014). ENGOs and website strategies for environmental sustainability. Serdang: UPM Press.

3. Aydin, G. K. (2010). Cultural Variability in Web Content: A Comparative Analysis of American and Turkish Websites. International Business Research, 3(1), 97-103. http://dx.doi.org/10.5539/ibr.v3n1p97

4. Bao, T. Q., \& Ellis, A. (2007). Assessing University Homepages from Web standard and usability perspectives. Retrieved from http://ausweb.scu.edu.au/aw07/papers/refereed/tran/paper.html

5. Brinck, T., Gergle, D., \& Wood, S. (2001). Usability for the Web: Designing Web sites that work. San Francisco: Morgan Kaufmann.

6. Burnett, R. \& Marshall, P. D. (2003). Web theory: An introduction. London: Routledge.

7. Dowling, G. R. (1994). Corporate reputations: Strategies for developing the corporate brand. London: Kogan Page.

8. Gray, E. R., \& Balmer, M. T. (1998). Managing corporate image and corporate reputation. Long Range Planning, 31(5), 695-702.

9. Hitlin, P., \& Rainie, L. (2005). Teens, technology, and school. In Pew Internet \& American Life Project. Retrieved from http://www.pewinternet.org/pdfs/PIP_Internet_and_schools_05.pdf

10. Ivory, M. Y. (2003). Automated website evaluation: Researchers' and practitioners' perspectives. Dordrecht: Kluwer Academic Press.

11. Kang, S., \& Norton, H. E. (2006). Colleges and Universities use of the World Wide Web: A public relations tool. Public relation, 32(4), 426-428.

12. McLachlan, K. (2002). WWW cyberguide ratings for website design. Retrieved February 2, 2016, from www.cyberbee.com/guides.html

13. Moore, M. G. (2004). Innovation and change. The American Journal of Distance Education, 1(4), 195-198.

14. Nichani, M. (2006). The Changing Face of University Websites. Retrieved from http://www.pebbleroad.com/ article/the changing_face_of_university_websites/

15. Nielsen, J. (2000). Designing web usability. Indianapolis, New Riders Publishing.

16. Nielsen, J., \& Tahir, M. (2002). Homepage Usability: 50 Websites Deconstructed. Indianapolis, IN, New Riders.

17. Nielsen, J. (2002). Coordinating User Interfaces for Consistency. San Francisco, Morgan Kaufman.

18. NOIE (National Office for the Information Economy). (2003). The current state of play: Online participation and activities. Australian Government, Canberra 2003. 
19. Scharl, A. (2006). Catalyzing environmental communication through evolving Internet technology. In Stephen P. DePoe (Ed.). The environmental communication yearbook, 3, 235-242. London: Lawrence Erlbaum Associates.

20. Sehmel, H. A. (2004). How a small environmental group uses the web to inform and promote action. In Arno Scharl (Ed.), Environmental online communication (pp. 45-52). London: Springer.

21. Sidhu, J. (2003). Mission statements: Is it time to shelve them? European Management Journal, 21, (4), 440-44.

22. Sinha, R., Hearst, M., \& Ivory, M. (n.d). Content or graphics? An empirical analysis of criteria for award-winning websites. Retrieved November 1, 2007, from http://webtango.berkely.edu/papers/hwf01/hwf01.htm

23. Spencer, T. (2002). The potential of the Internet for non-profit organizations. First Monday, 7(8). Retrieved September 6, 2005, from http://www.firstmonday.dk/issues/issue7$8 /$ spencer/index.html

24. Winn, W. \& Beck, K. (2002). The persuasive power of design elements on an e-commerce Web sites. Technical Communication, 49 (1), 17-35.

25. Jano, Z., Md. Noor, S., Ahmad, R., Md Saad, M. S., Saadan, R., Bokhari, M., and Abdullah, A. N., (2015). Website usability and cultural dimensions in Malaysian and Australian Universities. Asian Sosical Science, 11 (9). http://www.ccsenet.org/journal/index.php/ass/article/view/47140 